\title{
COMPARATIVE ANALYSIS OF ENTREPRENEURIAL INNOVATION FACTORS IN 25 NATIONAL STATES
} ANÁLISIS COMPARATIVO DE LOS FACTORES DE
INNOVACIÓN EMPRESARIAL EN 25 ESTADOS NACIONALES

\author{
Anca Elena Lungu \\ Alexandru loan Cuza University of lași, Romania \\ Ancalungu01@gmail.com \\ https://orcid.org/0000-0001-5086-8789
}

\section{Abstract}

At the base of entrepreneurship lies the challenge that individuals with entrepreneurial skills (entrepreneurs) must accept at the outset in an increasingly dynamic environment dominated by uncertainty. Innovation and the innovative process have to be constant in entrepreneurial actions. Building on this hypothesis, one cannot ignore the essentiality of the entrepreneur's adaptability to market requirements and demands. The assumption of risks and uncertainty evidently generates a motivation at an individual level in entrepreneur-actors. Action in a dynamic environment leads to the urgent necessity of adopting new technologies in business. From the perspective of implementing and using innovation, this study uses quantitative methods to illustrate the challenges related to innovation in the business environment. Our sample

\section{Resumen}

En la base del espíritu empresarial se encuentra el reto que los individuos con capacidades empresariales (empresarios) se proponen aceptar, en un entorno cada vez más dinámico y dominado por la incertidumbre. La innovación y el proceso innovador han de ser constantes en las acciones empresariales. Partiendo de esta hipótesis, no se puede ignorar la esencialidad de la adaptabilidad del empresario a las exigencias y demandas comprises 25 national states, selected according to their rank on the Global Entrepreneurship Index. Taking as a starting point the influence exerted by innovation and the innovative process within companies, we identify certain elements that justify the development level of entrepreneurship. Using Principal Component Analysis, we confirm that innovation, in its various forms (process, product, etc.); can significantly affect discrepancies among the countries. The three factorial axes resulting from the analysis of the main components (competition, product innovation and process innovation) explain the positioning of States on either side of the international hierarchy.

Keywords: entrepreneurship; challenges; business innovation; Global Entrepreneurship Index, Principal Component Analysis.

del mercado. La asunción de riesgos e incertidumbre genera evidentemente una motivación a nivel individual en los empresarios-actores. La actuación en un entorno dinámico lleva a la imperiosa necesidad de adoptar nuevas tecnologías en la empresa. Con el fin de identificar los retos a los que se enfrenta el entorno empresarial desde el punto de vista de la aplicación y el uso de la innovación, este estudio utiliza métodos cuantitativos 
para ilustrar los retos relacionados con la innovación en las empresas. La muestra está compuesta por 25 estados nacionales, seleccionados según su posición en el Índice Global de Emprendimiento. Identificamos ciertos elementos que justifican el nivel de desarrollo del espíritu empresarial, teniendo como punto de partida la influencia ejercida por la innovación y el proceso innovador dentro de las empresas. Utilizando el Análisis de Componentes Principales, confirmamos que la innovación, en sus diversas formas (proceso, producto, etc.), puede afectar significativamente a las discrepancias entre los países. Los tres ejes factoriales resultantes del análisis de los componentes principales (dimensión competitiva, dimensión de producto innovador y dimensión de proceso innovador) explican el posicionamiento de los Estados a uno y otro lado de la jerarquía internacional.

Palabras clave: espíritu empresarial; retos; innovación empresarial; Índice Global de Emprendimiento; Análisis de Componentes Principales

\section{Introduction}

At the core of any entrepreneurial activity lies an individual, i.e. the entrepreneur. Starting from this, we can agree on the unique and subjective character of each entrepreneurial activity. Literature observations on entrepreneurial activity can be addressed from different perspectives and, in this context; we aim to build a complementary approach to existing ones, illustrating the link between entrepreneurial activity and innovation. In order to fill a gap in the literature, we aim to offer some explanations for discrepancies between countries based on dissimilar attitudes towards innovation in the entrepreneurial activity.

At the base of entrepreneurship lies the challenge that individuals with entrepreneurial skills (entrepreneurs) set out to accept, in an increasingly dynamic environment dominated by risk and uncertainty (Knight, 1921). This action has the primary goal of obtaining some gains, irrespective of the type thereof, whether material or immaterial (Mises L. , 2018 [1949]) (Rothbard, 2001). The assumption of risks makes the difference between an entrepreneur and the other actors operating on a free marketplace, one where the rules of the game prevail. Identifying existing opportunities on a marketplace or creating new ones are specific activities of the entrepreneurial actor. Sooner or later, it is the consumers that will determine if the entrepreneur and the products or services they chose to develop were more or less inspired choices. Innovation and the innovative process have to be on-going and, implicitly, the adaptability to consumers' requirements and demands could give an individual a competitive edge on the market, to the detriment of their competitors. Performance and efficient use of available resources are goals that the entrepreneur pursues in conducting their own activity.

Action in a dynamic environment leads to the imperativeness of adopting new technologies in business. Even considering Vernon's opinion on product life-cycle, staticism can neither provide entrepreneurs with a market advantage, nor can it be maintained indefinitely. Innovation is the main tool entrepreneurs or companies can use to face the challenges of a free - and implicitly - competitive market. The discrepancies between countries can be explained, as our study demonstrates, by differences in terms of innovation adoption levels in entrepreneurial activity. Innovation and the innovative process have to be constant in entrepreneurial actions. Building on this hypothesis, one cannot ignore the essentiality of the entrepreneur's adaptability to market requirements and demands. The assumption of risks and uncertainty evidently generates a motivation at an individual level in entrepreneur-actors. 
The foremost purpose of this paper is to reiterate the degree to which the innovation affects the entrepreneurial activity. The main contribution of this research approach is its highlighting of how the current business activity is driven by the adoption of innovation for the 25 countries. This can be utilized both in practice and in theory. On the one hand, entrepreneurs can realize that the adoption of innovation must be a fundamental concern because this attitude makes the difference between profit and loss, whether to stay on or leave the market. On the other hand, the study may theoretically provide added value because the empirical analysis uses current data. However, there are also research limits that derive from a number of issues such as: heavier focus on explaining the impact of innovation on entrepreneurship and less so on explaining the impact of competitiveness, a very low number of entrepreneurshiprelated factors, and the limited sample. To develop the research, we aim to further expand the analysis to a large number of countries and to look at other dimensions that influence entrepreneurial activity, such as competitiveness.

The results of this research bear out that the major discrepancies between the selected study sample can be justified by differences in the area of innovation. We identified three eloquent dimensions that affect the country hierarchy in the world context. The first one refers to competitiveness across the marketplace. The second one is connected to the innovational dimension of products, and the last one is linked to the innovational dimension of the process. As demonstrate below, innovation in all its forms (process, product, etc.) - can significantly impact the discrepancies between countries.

The paper is structured as follows: the first part provides a concise presentation of the most important views on entrepreneurship and innovation, based on the author's focus on the approach of the Austrian School of Economics. The second part explains the research method employed, namely the Principal Component Analysis. Finally, the results and discussions section offers some clarifications for the discrepancies between countries in terms of entrepreneurship and innovation.

\section{Literature review}

Innovation is one of the fundamental premises for conducting entrepreneurial activities and for economic progress, respectively. The specialized literature often approached the impossibility of obtaining entrepreneurial profits without accepting the innovative element. Acting in a dynamic environment, entrepreneurs have to constantly innovate. Below we present the opinions regarding innovation as an element of the entrepreneurial act. The definition for 'entrepreneur' and the act they carry out took on different approaches throughout the analysis periods.

Innovation emerged as a matter of novelty in the definition of entrepreneurship. These approaches also include that of J.B. Say, who believes the entrepreneur is a middleman between the knowledge generating/producing scientist and the worker applying such knowledge in the industry (Say, 1821). Later on, Marshall put the entrepreneur's innovating function at the forefront, noting that the actor within the company is the one constantly seeking opportunities to cut costs (Marshall, 1875).

Joseph Schumpeter's contribution to developing a new meaning of innovation cannot be omitted from a specialized literature review. Schumpeter's entrepreneur does not need to be a capital owner or even work within the limits set by a company: the entrepreneur may, but need not, be the person who furnishes the capital 
(Schumpeter, 1939, p. 102). He introduced the idea of movement, i.e. a business operator that innovates. The irrationality thereof results from the lack of any economic calculation. The entrepreneur is a player that assumes the success or loss and is guided at the same time by a creative destruction (Schumpeter, 1942). Capitalism in itself is a change-generating system and, as such, cannot have a static dimension. The emergence of new goods, new production and distribution methods, new marketplaces, and new types of industrial organization is the impulse that guides the capitalist system and sets it in motion. In this context, each company and each entrepreneur has to adapt and innovate if they wish to survive. Creative destruction results from a critical mass of innovation or, in other words, from the entrepreneurs' action. Curiosity is what drives entrepreneurs to take action. The heroic character thereof is what drives them to take on new, unprecedented, and innovative actions. Innovation is what enables the entrepreneur to expand their business and consolidate their market position, pushing the boundaries of their own market by setting new rules under uncertainty conditions. Thus, Schumpeter defines entrepreneurship from an economic perspective, emphasizing the idea of identifying market opportunities and adapting same by means of innovation.

Largely sharing Schumpeter's vision, Frank Knight states that innovation is a source of profit and can only occur when investments are used to create new resources. Knight sees the entrepreneur's motivation as connected to the desire to excel, to win a game, the greatest and most fascinating game that was ever invented. In order to achieve gains, there are three tasks incumbent on the entrepreneur: (1) to initiate change and usher in innovations; (2) to adapt to changes in the economic environment; (3) to assume the consequences of the uncertainties they are faced with in the activity carried out within the company. Knight's analysis emphasizes the intuitive and game-like nature of the entrepreneurial act, as well as the irrationality guiding the entrepreneur. The skills required of an entrepreneur are different from those pertaining to other individuals, conferring a prophetic characteristic upon the entrepreneur, provided that the market is well organized. The entrepreneur assumes the uncertainty in order to earn a profit by satisfying consumers' needs, while acting in an innovative manner (Knight, 1921).

Friedrich von Hayek believes that business operators make decisions in a context dominated by uncertainty rather than in a transparent one, as postulated in the hypothetical case of perfect competition. Entrepreneurship signifies the pursuit, discovery, and adjustment of the actions of business operators who are actively promoting the changes defining the market process. In other words, in Hayek's vision entrepreneurship is the relation between competition and knowledge, rooted in the condition that every business operator has a specific advantage in their subjective knowledge. Discovery and innovation are the ones that ensure the market evolution and entail benefits for the entrepreneur (Hayek F. A., 1960) (Hayek F. , 1988) (Hayek F. , 2014).

For Kirzner, the entrepreneur is not a source of ex nihilo innovation, but rather an agent in constant pursuit of existing opportunities waiting to be identified. In the process of economic development, the entrepreneur should be seen as one who responds to opportunities instead of a creator thereof. The entrepreneur notices opportunities that can generate profits (Kirzner, 1973).

In recent years, the terms innovation and entrepreneurship have gained quite the importance in management literature. In one of his works, Peter Drucker approaches entrepreneurship building on the philosophy according to which, in the present and 
in the future, the entrepreneurial society may be the only one capable of supporting the development of a welfare society. This entrepreneurial society will be the result of an economy based on innovative entrepreneurship, combined with easy government or, otherwise said, minimum intervention in regards to development (Drucker, 1985). In his opinion, innovation is the specific tool of entrepreneurs, the means they use to capitalize on change as an opportunity for a different business or a different service. It can be presented as a discipline, and it can be learned and practiced. Entrepreneurs need to search purposefully for the sources of innovation, the changes and their symptoms that indicate opportunities for successful innovation (Drucker, 1985, p. 20). $\mathrm{He}$ introduces the idea of systematic innovation as a framework for the exploitation of innovative opportunities and identifies several sources of innovation: (1) the unexpected; (2) incongruity; (3) innovation based on the needs of the process; (4) changes in the sector or in the market structure that surprise everybody; (5) changes in the number and structure of the population; (6) changes in terms of perception, status and significations; (7) new knowledge, both scientific and non-scientific. Peter Drucker lays emphasis on the need for innovation and entrepreneurship in a society. In order to achieve this, entrepreneurial executives have to transform innovation and entrepreneurship into normal, everyday, and ongoing activities.

William Baumol states that innovation is the driving force that leads to the remarkable progress of capitalism (Baumol W. , 2002). In the capitalist economy, innovation is the primary dimension of the competitive process, to the detriment of prices, and less competitive companies lose their market position in favor of their competitors. To this end, innovation is an essential element that can ensure the survival of the company. Moreover, Baumol developed a few ideas to prove that innovation can be integrated in the neoclassical framework. The latter describes a process whereby companies compete with one another based on innovation rather than prices, emphasizing that successful companies may be ineffective from a neoclassical point of view, but they can enjoy profits if they continue to innovate. Without innovation, even the most efficient company will be ousted from the market by innovative competitors. Thus, the only solution is to routinize innovation, making it a part of the activities conducted across the company. Market incentives force companies to constantly innovate, which led to the miracle growth of capitalism. Baumol views the entrepreneur as an independent innovator, in the broadest sense, meaning that the activities of this individual include, but go considerably beyond, technical inventions and their utilization (Baumol W. , 2002, p. 114). Moreover, the importance of market institutions and the protection of ownership rights are mandatory in order to ensure the necessary incentives for profitgenerating innovation. In Baumol's vision, the fact that constant refinement became rather routinized seems to be the argument for the continued progress that requires cultivating a spark of entrepreneurship, able to generate the real miracle of the freemarket innovation machine. In brief, innovation begets innovation.

Recent studies in the specialized literature bring to the foreground the role of innovation in the process of economic development. Jorgenson's opinion runs along the same lines, stating that achieving economic growth is based on introducing new innovations in the field of technology by integrating same in different domains or fields of activity. He emphasizes that the innovative process based on technology led to significant growth rates in the economic sectors (Jorgenson D. W., 2011). In small businesses, new innovations and their related activities have contributed to an increased observance of copyrights by large companies (Kortum, S., Lerner, J., 2000). Galindo et. al believes that the entrepreneurs' decisions to innovate or not are tightly connected to the achievement of profits; implicitly, we can identify a circular process given that innovation can be 
assimilated to the improvement of a product, granting the entrepreneur a better position on the competitive market. The latter are relevant for obtaining increasingly higher profits that can be applied for new innovation. This circuit also has positive effects on economic growth (Galindo, M.A., Mendez-Picazo, M.T., 2013).

In Bhide's view, entrepreneurial firms are in fact relatively young structures that have the potential to grow and achieve profit over relatively short time frames (Bhide, 2000). Amit \& Zott state that for a company, an innovative business model can lay the foundation for creating a new market or can offer the possibility to introduce and harness new entrepreneurial opportunities that already exist on an established marketplace (Amit, R., Zott, C., 2013). Acting in such a context, these companies should offer solutions to the problems people encounter in an ever-changing world (Langlois, 2005).

Covin \& Slevin and Chell once again bring to the fore one of the main characteristics of an entrepreneur. Besides the risk-bearing capacity, they highlight the entrepreneur's ability to innovate in order to obtain new products or services, new technologies or new processes (Covin, J.G., Slevin, D.P., 1986) (Chell, 2008). Brem and Voigt state that the access to external resources supports the innovating capacity of businesses, in particular by developing the knowledge of entrepreneurs and by increasing the inclination to use the new (Brem, A., Voigt, K. , 2007). Lassen et al. points out that entrepreneurs decide to develop R\&D departments in order to encourage innovation (Lassen, A.H., Gertsen, F., Riis, J.E., 2006). Knowledge helps innovation-driven entrepreneurship in achieving economic development (Bosma, 2013) and can include new processes, new organizational designs, or new product-market combinations (Cliff, J.E., Jennings, D. J, Greenwood, R., 2006). To synthesize the aforementioned opinions, we can posit that specialized literature also confirms the statement according to which the dimension of the entrepreneurial activity is significantly influenced by the degree of implementation of technologies or new technologies.

\section{Methods and Materials}

This research analyses the influence of innovation on entrepreneurial activity. Considering the goal set for this article, i.e. to identify the entrepreneurial discrepancies between countries from the perspective of implementing and using innovation, the research methodology employed helps prove the established hypothesis. We aim to answer to the following research question:

Can we explain the discrepancies between the selected countries in terms of entrepreneurial activity through innovation?

In order to achieve the purpose of the research, the article starts with a review of specialized literature, illustrating the most important opinions on innovation and entrepreneurship. Starting from this review, we aimed to empirically illustrate the statements posited in the literature. For the empirical part of the research endeavor, we sourced available data on entrepreneurship, as well as on the innovative dimension of the activity conducted by individuals with entrepreneurial skills. Under these circumstances and having a very low number of entrepreneurship-related factors as the primary limitation, we used the Global Entrepreneurship Index. This index is provided by The Global Entrepreneurship and Development Institute (The GEDI Institute), founded by world-leading entrepreneurship scholars from the LSE, George Mason University, University of Pécs, and Imperial College London. 
To have a clear view of the database, we need to make some notes regarding the analyzed indicators. We chose two sub-indices in the componence of which we can identify elements that are able to view the innovative phenomenon in a most evident manner (Abilities Subindex and Aspirations Subindex). Each sub-index takes values from 0 to 1 , where 0 is the lowest and 1 is the highest.

The Abilities Sub-Index includes the following components:

- Opportunities Start-up monitors the identification of individuals that are guiding their activity for the purpose of identifying certain quality opportunity-driven startups, while also considering the effects of taxation and those related to the quality of governmental services.

- Technology Absorption is the variable used to measure the capacity of a state to implement and absorb new technologies via companies. This measurement is obtained following the World Economic Forum reporting. The diffusion of new technology, and the capability to absorb it, is vital for innovative firms with high growth potential (Acs, Z., Szerb, L., Lloyd, A., 2018).

- The Human Capital pillar captures the quality of entrepreneurs as weighing the percentage of start-ups founded by individuals with higher than secondary education with a qualitative measure of the propensity of firms in a given country to train their staff combined with the freedom of the labor market(Acs, Z., Szerb, L., Lloyd, A., 2018).

- Competition measures whether entrepreneurs are able to create new products and services they can subsequently introduce on the market.

The Aspiration Sub-Index includes the following components:

- Product Innovation refers to a company's capacity to create new products that reflect the transfer capacity of a country's technology. This indicator measures a country's potential to create new products or mimic existing products via innovation.

- Process Innovation: The Process Innovation pillar captures the use of new technologies by start-ups combined with the Gross Domestic Expenditure on Research and Development (GERD) and the potential of a country to conduct applied research (Acs, Z., Szerb, L., Lloyd, A., 2018).

- High Growth identifies a company's capacity to plan its growth strategy and measures its capacity to grow, setting ambitious goals for itself in terms of gaining profits.

- Internationalization centralizes and measures the extent to which companies are able to identify opportunities on the international market for exporting their products or services.

- Capital Risk refers to the availability of capital both for natural persons and institutions.

The data collected for subsequent analysis is provided in Table 1. The analyzed sample comprises 25 states, and the selection criterion thereof was related to their rank on the Global Entrepreneurship Index. In their case, we aimed to identify certain elements that justify the development level of entrepreneurship, having the influence exercised by innovation and the innovative process within companies as their starting point. 
Table 1: The Global Entrepreneurship Index and Sub-Index Ranks of the First 25 Countries, 2018

\begin{tabular}{|c|c|c|c|c|c|c|c|c|c|c|c|c|}
\hline Countries & Ш্ত & 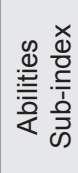 & 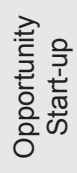 & 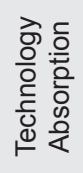 & 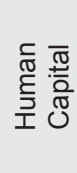 & 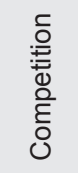 & 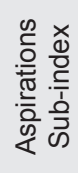 & 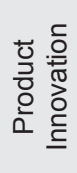 & 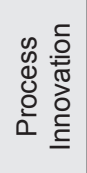 & 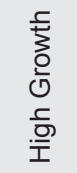 & 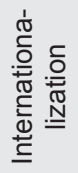 & 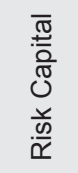 \\
\hline $\begin{array}{l}\text { United } \\
\text { States }\end{array}$ & 83.60 & 86.00 & 0.849 & 0.814 & 1.000 & 1.000 & 84.90 & 0.733 & 0.902 & 1.000 & 1.000 & 0.876 \\
\hline Switzerland & 80.40 & 86.40 & 0.966 & 1.000 & 0.789 & 1.000 & 85.50 & 0.834 & 0.902 & 0.882 & 1.000 & 1.000 \\
\hline Canada & 79.20 & 79.90 & 0.999 & 0.779 & 0.912 & 0.676 & 79.90 & 0.991 & 0.758 & 0.559 & 0.936 & 1.000 \\
\hline $\begin{array}{c}\text { United } \\
\text { Kingdom }\end{array}$ & 77.80 & 83.30 & 0.925 & 1.000 & 0.742 & 0.848 & 76.30 & 0.924 & 0.701 & 0.850 & 0.824 & 0.649 \\
\hline Australia & 77.50 & 76.00 & 0.871 & 0.780 & 0.950 & 0.567 & 71.20 & 0.592 & 0.786 & 0.658 & 0.633 & 1.000 \\
\hline Denmark & 74.30 & 84.50 & 1.000 & 1.000 & 1.000 & 0.989 & 66.50 & 0.988 & 0.723 & 0.594 & 0.390 & 1.000 \\
\hline Iceland & 74.20 & 69.90 & 1.000 & 1.000 & 0.506 & 0.501 & 70.30 & 0.602 & 0.838 & 0.699 & 0.952 & 0.588 \\
\hline Ireland & 73.70 & 78.90 & 1.000 & 0.769 & 0.851 & 1.000 & 75.00 & 1.000 & 0.822 & 0.884 & 0.970 & 0.568 \\
\hline Sweden & 73.10 & 78.70 & 0.976 & 0.946 & 0.644 & 0.869 & 69.50 & 0.666 & 0.899 & 0.557 & 0.816 & 0.721 \\
\hline France & 68.60 & 69.70 & 0.683 & 0.840 & 0.625 & 0.739 & 74.40 & 0.801 & 0.941 & 0.644 & 0.764 & 0.768 \\
\hline Netherlands & 68.10 & 65.30 & 0.935 & 0.835 & 0.365 & 0.786 & 61.70 & 0.652 & 0.769 & 0.596 & 0.562 & 0.715 \\
\hline Finland & 67.90 & 62.90 & 1.000 & 0.826 & 0.495 & 0.415 & 61.80 & 0.617 & 0.795 & 0.675 & 0.647 & 0.497 \\
\hline Hong Kong & 67.30 & 62.50 & 0.800 & 0.643 & 0.894 & 0.381 & 70.20 & 0.884 & 0.409 & 1.000 & 0.679 & 1.000 \\
\hline Austria & 66.00 & 66.40 & 0.808 & 0.941 & 0.399 & 0.761 & 64.40 & 0.724 & 0.818 & 0.403 & 0.901 & 0.630 \\
\hline Germany & 65.90 & 67.20 & 0.759 & 0.863 & 0.482 & 0.848 & 69.40 & 0.667 & 0.84 & 0.662 & 0.874 & 0.760 \\
\hline Israel & 65.40 & 60.80 & 0.647 & 1.000 & 0.811 & 0.317 & 72.20 & 0.997 & 1.000 & 0.851 & 0.601 & 0.788 \\
\hline Belgium & 63.70 & 67.80 & 0.543 & 0.852 & 0.778 & 0.850 & 69.50 & 0.913 & 0.963 & 0.551 & 0.887 & 0.627 \\
\hline Taiwan & 59.50 & 54.80 & 0.651 & 0.705 & 0.701 & 0.317 & 69.56 & 0.972 & 0.696 & 0.894 & 0.535 & 0.935 \\
\hline Chile & 58.50 & 50.90 & 0.812 & 0.550 & 0.670 & 0.370 & 54.30 & 1.000 & 0.320 & 0.670 & 0.370 & 0.640 \\
\hline $\begin{array}{c}\text { Luxem- } \\
\text { bourg }\end{array}$ & 58.20 & 62.90 & 1.000 & 0.839 & 0.551 & 0.857 & 62.60 & 1.000 & 0.612 & 0.545 & 1.000 & 0.902 \\
\hline Norway & 56.60 & 60.90 & 1.000 & 0.752 & 0.419 & 0.671 & 42.84 & 0.259 & 0.465 & 0.467 & 0.282 & 0.840 \\
\hline Qatar & 55.00 & 54.50 & 0.754 & 0.339 & 0.882 & 0.603 & 62.20 & 0.856 & 0.516 & 1.000 & 0.529 & 0.956 \\
\hline Estonia & 54.80 & 55.70 & 0.635 & 0.773 & 0.540 & 0.606 & 50.95 & 0.724 & 0.647 & 0.674 & 0.658 & 0.214 \\
\hline Korea & 54.20 & 50.10 & 0.485 & 0.460 & 0.560 & 0.320 & 56.80 & 0.950 & 1.000 & 0.450 & 0.320 & 0.580 \\
\hline Slovenia & 53.80 & 55.00 & 0.604 & 0.744 & 0.500 & 0.485 & 52.09 & 0.480 & 0.806 & 0.427 & 0.746 & 0.333 \\
\hline
\end{tabular}

Source: own processing of data available on The Global Entrepreneurship and Development Institute (2018)

Upon the initial analysis of the data registered by the indicators/indices related to entrepreneurship and innovation, we drew a series of logical correlations between same and the market reality in the respective states in order to offer ideological and theoretical justifications. Moreover, we used the Principal Component Analysis to reduce the number of variables and identify the primary components impacting entrepreneurship and business innovation. 


\section{Results and Discussions}

In order to identify the existence of correlations between variables, we considered the Kaiser-Meyer-Olk in Measure of Sampling Adequacy. In the case of analyzed variables, $\mathrm{KMO}>\propto \rightarrow 0.608>0.05$, which means there are correlations between the variables. Given that $\mathrm{KMO}>0.5$, the analysis of the primary components can be applied.

KMO and Bartlett's Test

\begin{tabular}{|c|c|c|}
\hline \multicolumn{2}{|c|}{ Kaiser-Meyer-Olkin Measure of Sampling Adequacy. } & .614 \\
\hline \multirow{3}{*}{ Bartlett's Test of Sphericity } & Approx. Chi-Square & 65.749 \\
\cline { 2 - 3 } & Df & 36 \\
\cline { 2 - 3 } & Sig. & .002 \\
\hline
\end{tabular}

Communalities

\begin{tabular}{|c|c|c|}
\cline { 2 - 3 } \multicolumn{1}{c|}{} & Initial & Extraction \\
\hline Opportunity_Start_up & 1.000 & .859 \\
\hline Technology Absorption & 1.000 & .708 \\
\hline Human_Capital & 1.000 & .799 \\
\hline Competition & 1.000 & .673 \\
\hline Product_Innovation & 1.000 & .620 \\
\hline Process_Innovation & 1.000 & .781 \\
\hline High_Growth & 1.000 & .588 \\
\hline Internationalization & 1.000 & .670 \\
\hline Risk_Capital & 1.000 & .635 \\
\hline
\end{tabular}

Extraction Method: Principal Component Analysis.

Total Variance Explained

\begin{tabular}{|c|c|c|c|c|c|c|c|c|c|}
\hline \multirow{2}{*}{ 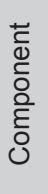 } & \multicolumn{3}{|c|}{ Initial Eigen values } & \multicolumn{3}{|c|}{$\begin{array}{l}\text { Extraction Sums of Squared } \\
\text { Loadings }\end{array}$} & \multicolumn{3}{|c|}{$\begin{array}{c}\text { Rotation Sums of Squared } \\
\text { Loadings }\end{array}$} \\
\hline & Total & $\begin{array}{c}\% \text { of } \\
\text { Varian- } \\
\text { ce }\end{array}$ & $\begin{array}{l}\text { Cumu- } \\
\text { lative \% }\end{array}$ & Total & $\begin{array}{c}\% \text { of } \\
\text { Varian- } \\
\text { ce }\end{array}$ & $\begin{array}{c}\text { Cumu- } \\
\text { lative } \\
\%\end{array}$ & Total & $\begin{array}{c}\% \text { of } \\
\text { Varian- } \\
\text { ce }\end{array}$ & $\begin{array}{c}\text { Cumu- } \\
\text { lative } \\
\%\end{array}$ \\
\hline 1 & 2.574 & 28.603 & 28.603 & 2.574 & 28.603 & 28.603 & 2.401 & 26.682 & 26.682 \\
\hline 2 & 2.334 & 25.934 & 54.537 & 2.334 & 25.934 & 54.537 & 2.350 & 26.115 & 52.797 \\
\hline 3 & 1.425 & 15.829 & 70.367 & 1.425 & 15.829 & 70.367 & 1.581 & 17.570 & 70.367 \\
\hline 4 & .717 & 7.968 & 78.335 & & & & & & \\
\hline 5 & .604 & 6.707 & 85.041 & & & & & & \\
\hline 6 & .508 & 5.646 & 90.687 & & & & & & \\
\hline 7 & .364 & 4.044 & 94.731 & & & & & & \\
\hline 8 & .252 & 2.796 & 97.527 & & & & & & \\
\hline 9 & .223 & 2.473 & 100.000 & & & & & & \\
\hline
\end{tabular}

Extraction Method: Principal Component Analysis. 
Following the analysis of the data processing results, we can note that the first three components explain $70.36 \%$ of the total corresponding to the total variance, as follows:

The first component (component 1) explains $28.603 \%$ of the total variance;

The second component (component 2) explains $25.934 \%$ of the total variance;

The third component (component 3) explains $15.829 \%$ of the total variance.

Each of the three components is comprised of several variables, as evidenced in the table below:

\section{Component Matrix}

\begin{tabular}{|c|c|c|c|}
\cline { 2 - 4 } \multicolumn{1}{c|}{} & \multicolumn{3}{c|}{ Component } \\
\cline { 2 - 4 } \multicolumn{1}{c|}{} & 1 & 2 & 3 \\
\hline Opportunity_Start_up & .534 & -.176 & -.736 \\
\hline Technology Absorption & .535 & -.649 & .007 \\
\hline Human_Capital & .608 & .630 & .181 \\
\hline Competition & .715 & -.379 & -.135 \\
\hline Product_Innovation & .351 & .526 & .469 \\
\hline Process_Innovation & .251 & -.512 & .675 \\
\hline High_Growth & .455 & .610 & .099 \\
\hline Internationalization & .661 & -.419 & .240 \\
\hline Risk_Capital & .540 & .505 & -.298 \\
\hline
\end{tabular}

Extraction Method: Principal Component Analysis.

a. 3 components extracted.

\section{Component Transformation Matrix}

\begin{tabular}{|c|c|c|c|}
\hline Component & 1 & 2 & 3 \\
\hline 1 & .718 & .592 & .367 \\
\hline 2 & -.650 & .758 & .049 \\
\hline 3 & .249 & .273 & -.929 \\
\hline
\end{tabular}

Extraction Method: Principal Component Analysis.

Rotation Method: Varimax with Kaiser Normalization.

In order to note the main dimensions that impact variance, we resorted to synthesizing the information on the components. Following this process, we decided that there were three dimensions with significant impacts on the entrepreneurial attitude of business actors in the analyzed sample:

The first dimension (component 1) pertains to competitiveness across the marketplace. This one is significantly impacted by the human capital involved in the competitive process, as well as by the companies' capacity for internationalization.

The second dimension (component 2) - the innovational dimension of the product; The third dimension (component 3) - the innovational dimension of the process.

The Principal Component Analysis generated 3 new variables that describe the three dimensions listed above, named Fac1_1, Fac2_1, Fac3_1, which refer to the influence of the independent variable on the dependent variable. In our case, 
the dependent variable is Fac2_1 which represents the innovational dimension of the product, and Fac1_1 is the independent variable, pertaining to the competitive dimension. The values of the new variables are highlighted in Table 2. Moreover, Figure 2 is a graphical representation of the values mentioned in table 2.

Figure 1: Component Plot in Rotated Space

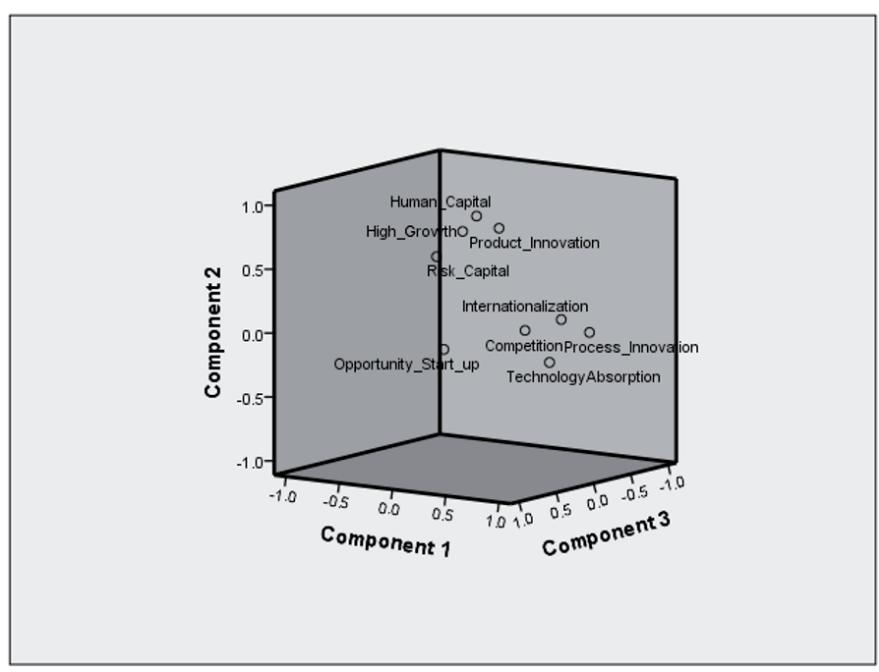

Source: SPSS output for the used database

Figure 2: REGR factor score for analysis

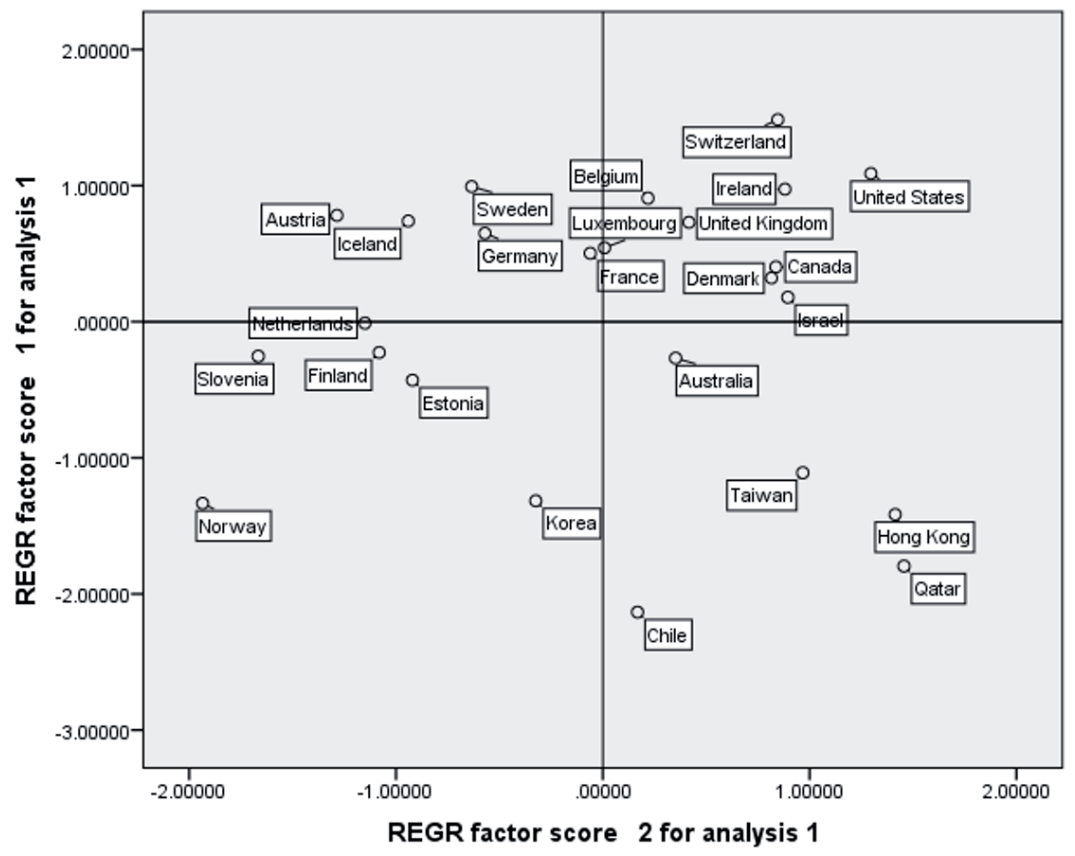


Table 2: Factor Variable of the First 25 Countries, 2018

\begin{tabular}{|c|c|c|c|}
\hline Countries & $\begin{array}{c}\text { FAC1_1 } \\
\text { (Competitive } \\
\text { Dimension) }\end{array}$ & $\begin{array}{c}\text { Fac2_1 } \\
\text { (Product } \\
\text { Innovation) }\end{array}$ & $\begin{array}{c}\text { Fac3_1 } \\
\text { (Process } \\
\text { Innovation) }\end{array}$ \\
\hline Switzerland & 1.08806 & 1.29629 & 0.14802 \\
\hline United States & 1.48408 & 0.8459 & 0.6503 \\
\hline Denmark & 0.40211 & 0.83687 & 0.55372 \\
\hline United Kingdom & 0.73008 & 0.41649 & 0.3416 \\
\hline Canada & -0.2677 & 0.35198 & 0.578 \\
\hline Ireland & 0.32116 & 0.81559 & 1.1272 \\
\hline Sweden & 0.7395 & -0.9406 & 0.30345 \\
\hline Australia & 0.97353 & 0.88062 & 0.09679 \\
\hline Iceland & 0.99239 & -0.6341 & 0.46418 \\
\hline France & 0.50233 & -0.06087 & -0.83475 \\
\hline Belgium & -0.01051 & -1.15031 & 0.64261 \\
\hline Germany & -0.2263 & -1.08117 & 0.23343 \\
\hline Austria & -1.41662 & 1.41383 & 0.66489 \\
\hline Netherlands & 0.78107 & -1.28558 & -0.20476 \\
\hline Luxembourg & 0.65024 & -0.57017 & -0.11701 \\
\hline Finland & 0.17878 & 0.89441 & -1.53592 \\
\hline Hong Kong & 0.90769 & 0.21851 & -1.6496 \\
\hline Japan & -1.10972 & 0.96701 & -0.66425 \\
\hline Norway & -2.1336 & 0.16752 & 0.34597 \\
\hline Israel & 0.54307 & 0.00801 & 0.92684 \\
\hline Singapore & -1.33455 & -1.9354 & 2.17666 \\
\hline Estonia & -1.79574 & 1.45621 & 0.35854 \\
\hline Slovenia & -0.42935 & -0.92039 & -1.0313 \\
\hline Taiwan & -1.31616 & -0.32428 & -2.39118 \\
\hline Qatar & -0.25386 & -1.66638 & -1.18342 \\
\hline
\end{tabular}

By performing an analysis of the factorial axes obtained, we can draw the following conclusions:

(1) On the first factorial axis, corresponding to the competitive dimension, the highest values are registered by countries such as the United States, Switzerland, Iceland, Australia, and Hong Kong, and the lowest values are achieved by Norway, Estonia, Austria, Singapore, and Taiwan. We can infer that in the case of the highest ranking states, the behavior of business actors is one that tends towards carrying out the entrepreneurial act and is implicitly indicative of a strong competitive process. The status of the United States of America once again emphasizes their international competitiveness, which evidently correlates with their economic development. On the opposite side, in the case of countries ranking lowest in terms of the competitive dimension, we can conclude that an analysis should be performed on the factors determining the entrepreneurs' lack of focus on the wish to be constantly enterprising 
within the competitive process. Some the factors that might explain this lack of action could be the laws in the respective country and the obstacles business actors encounter in conducting the entrepreneurial act. Aside from this aspect, we could consider the cultural dimension corresponding to each country, as well as its implications in terms of entrepreneurship. Given that we have yet to see any research on the social and political, legal or cultural conditions in the analyzed states, we cannot accurately state the causes for such low values in the entrepreneurial behavior, focused on participation in the market process.

(2) The dimension that refers to the innovational product corresponds to the second factorial axis. As with the first factorial axis, there are significant differences in the analyzed countries. Thus, entrepreneurs in states at the top of the hierarchy are more motivated to innovate their product than those at the bottom. On the one hand, there are countries where motivation and the perception of opportunity score very high values (Estonia, Austria, Switzerland, Japan, and Finland); while in other countries the same indicators score very low (Singapore, Qatar, Netherlands, Belgium, and Germany). In the product innovation dimension, the Human Capital component also has a major significance. Considering this aspect, we can state that the different cultural heritage is one of the factors worth mentioning in this dimension. While for some people entrepreneurship seems to be something that comes naturally, for others we can talk about the attempt to educate the same values. Furthermore, the differences in terms of political regime evidently bear another type of impact on understanding the discrepancies in terms of the motivational dimension. In studies centered on the analysis of innovation and government intervention in Singapore and Hong Kong, Wang and Young make similar observations regarding the innovation (Wang, 2018) (Young, 1992).

(3) The third factorial axis can be associated with the innovative process dimension. Singapore, Ireland, Israel, Austria, and the United States rank at the top of the list in terms of implementing innovative strategies within processes. On the other hand, entrepreneurs in Taiwan, Hong Kong, Finland, Qatar, and Slovenia score the lowest values in terms of implementing new processes within companies. For this factorial axis we can draw the same correlation regarding the national culture and the focus towards entrepreneurship.

Starting from the observation of factorial axes, we can notice a series of interesting aspects regarding certain states in the study sample:

The United States of America score very high values for the first factorial axis (the competitive dimension) and very low values for the third factorial axis (the innovational process dimension). Opportunity start-up and Risk capital negatively impact the last factorial axis, which means that both the innovative product dimension and the innovative process dimension are influenced by competition on the American marketplace. The entrepreneur's activity bears the mark of competitiveness, in which we also include both Internationalization and Human Capital. The USA's position in international trade is well understood and, moreover, we can identify the challenges the USA faces in starting a business, building on the idea of innovation. This idea is also advanced by Sayton and Mangematin (Stayton, J., Mangematin, V., 2016). Furthermore, in a VUCA world, the need for innovation is clearly highlighted and competitiveness leads to adaptability (Schoemaker, P.J.H., Heaton, S., Teece, D., 2018).

Switzerland presents high values for both the first and second factorial axes, and this data could suggest the significant connection between the high level of 
competitiveness and the high level of innovation in terms of products designed for consumers. Another major aspect worth mentioning for Switzerland refers to the value of the third variable focusing on the innovative process dimension. In spite of a high level of competitiveness and innovation in terms of the process, the innovative process generally scores relatively low values; we could thus infer that change is rather difficult in major sectors that contribute to the economic development of Switzerland (e.g.: the watchmaking industry they are notorious for, etc.). Recent studies have demonstrated that Swiss businesses are in constant pursuit of innovation. Moreover, the literature provides observations about the high level of competitiveness (Papula, J., Kohnova, L., Papulova, Z., 2018) (Eker, 2016).

Singapore is located at the top of the list for the third factorial axis, which refers to the process innovation dimension. The same state scores the lowest values in the second factorial axis (product innovation) and relatively low values in the first factorial axis. Thus we can infer that Singapore innovates in terms of process, yet without implicitly bringing about changes in terms of the finished product designed for consumers. Moreover, competition does not appear to be stimulated on the Singaporean marketplace. The results of previous studies have demonstrated that Singapore promotes decentralization inside the companies and, through it, the employees are encouraged to innovate and believe in innovation (Wan, D., Huat Ong, C., Lee, F., 2005) (Kanter, 1988) (Damanpour, 1991) (Yam, R.C.M., Lo, W., Tang, E.P.Y., Lau, A.K.W., 2011).

Japan registers very high values for the second axis (product innovation) and negative values for the other two factorial axes. In a similar study, Henrekson and Sanandaji demonstrate that this situation can indicate a predominance of large established enterprises, old family-run businesses, or public-sector employment (Henrekson, M., Sanandaji, T. , 2019).

Innovation is one of the most important influence factors in the entrepreneurial activity. In a similar research, Avanzizi admits that innovation in business represents the foundation for economic development (Avanzini, 2009). In conclusion, following the empirical analysis, we have ascertained three dimensions that explain the variations in entrepreneurship: the competitive dimension, the innovational dimension of the product, and the innovational dimension of the process. While being a limitation for the current research endeavor, putting together a map that illustrates the entrepreneurial intensity and, moreover, the level of economic development in countries across the world, will constitute a future research direction.

\section{Conclusions}

A literature review was undertaken and, in the second part of the paper, an empirical demonstration has been developed in order to answer the research question. The primary challenges that entrepreneurs and companies face are related to the capacity to adapt to new trends by using innovation and the innovative process. By acting in an innovative manner, entrepreneurs manage to obtain a proper positioning in the market hierarchy and, moreover, they can hope for maximized profits. Most of the times, the difficulty in implementing the innovative process and product innovation incentivizes entrepreneurs in their activity. We can state that the answer for the research question was identified: we have explained the discrepancies between the selected countries in terms of entrepreneurial activity through innovation. 
The results obtained using the Principal Component Analysis have highlighted major aspects in regards to differences between the countries in the study sample, and the causes for these discrepancies should be subject to observation. We can conclude that the highest values of the competitive dimension are registered by countries such as the United States, Switzerland, Iceland, Australia, and Honk Kong, which can be interpreted as a very high competitiveness in the entrepreneurial activity in these areas. The competition drives the entrepreneurs to be highly performant in their activities, to bear uncertainty and, most importantly, to gain profits based on said performance. On the other hand, we note the lowest values of the competitive dimension in countries such as Norway, Estonia, Singapore, and Taiwan, which affect the entrepreneurs' lack focus on the competitive process; however, we can note that some of the aforementioned countries (such as Taiwan) also score low in terms of process innovation. The lowest scores for product innovation suggest that the entrepreneurs ranked at the bottom of the hierarchy are less motivated to implement innovation in their new products. This statement offers a justification for the situation in countries such as Qatar, the Netherlands, Belgium or Germany. Regarding the structure of the product innovation dimension, we cannot ignore the significance of the human capital component, which can affect the entrepreneurial process by virtue of the culture. The third dimension is related to the innovative process. At the top of the list here we can rank countries such as Singapore, Ireland, and the United States of America. On the other hand, the lowest values are registered in Taiwan, Honk Kong, Finland, Qatar, etc. In fact, this axis illustrates the extent to which the new process is implemented in the entrepreneurial activity. We should mention the situation in Singapore: the country is at the top of the list in terms of process innovation, but scores the lowest values in product innovation or in the competitive dimension of the market. The competition is very high in the United States of America, but the innovational process is at the opposite side of the hierarchy, which means that American entrepreneurs must be very competitive even if they are not very innovative in terms of process or product.

Part of the differences can be generally justified, but one should not omit the particular aspects that generate heterogeneity. The political regime, entrepreneurial culture (and others), and the risk susceptibility of a nation provide explanations for the entrepreneurial activity of its actors. In the analyzed sample we can undoubtedly notice the heterogeneity starting from their very own cultural, social, and political differences. As was already shown, the three factorial axes resulting from the analysis of the main components offer a series of explanations for the positioning of states on either side of the international hierarchy, precisely by tapping already existing information that were set in a different light.

The added value of this research resides in reiterating the importance of innovation in any entrepreneurial activity. Therefore, the implications in theory and practice alike can be easily discovered. Firstly, the empirical study can be used by practitioners to highlight the vital innovativeness in their organizations. Secondly, the literature can benefit from a new demonstration of the same argument, based on recently collected data. Finally, we acknowledge the limitations of this research, considering the limited number of analyzed countries, the prevailing focus on innovation and less so on competitiveness, but these limitations will constitute new research directions. 


\section{References}

Acs, Z. J., Audretsch, D. B. (1987). Innovation, market structure, and firm size. Review of Economics and Statistics, 69(4), 567-574.

Acs, Z. J., Audretsch, D. B. (1988). Innovation in large and small firms: An empirical analysis. American Economic Review, 78(4), 678-690.

Acs, Z., Szerb, L., Lloyd, A. (2018). The Global Entrepreneurship Index. Washington: The Global Entrepreneurship and Development Institute.

Acs, Z., Szerb, L., Lloyd, A. (2018). The Global Entrepreneurship Index. Technical Annex. Washington: The Global Entrepreneurship and Development Institute.

Amit, R., Zott, C. (2013). Business Model Innovation: Creating Value In Times Of Change. MIT Sloan Management Review, 53(3), 41-49.

ANNA. (2016, August 31). London to New York market stable at just over four million annual pax. Retrieved from Airline Network News and Analysis: https://www.anna. aero/2016/08/31/london-to-new-york-market-analysed/

Avanzini, D. (2009). Designing composite entrepreneurship indicators: An application using consensus PCA. WIDER Research Paper, No. 2009/41, ISBN 978-92-9230212-2, The United Nations University World Institute for Development Economics Research (UNU-WIDER), Helsinki.

Baumol, W. (2002). The Free-Market Innovation Machine: Analyzing The Growth Miracle Of Capitalism. Princeton: Princeton University Press.

Baumol, W. J. (1968). Entrepreneurship in Economic Theory. American Economic Review, 58(2), 64-71.

Bhide, A. (2000). The Origin and Evolution of New Businesses. New York: Oxford University Press.

Böhm-Bawerk, E. (1930 [1889]). The Positive Theory of Capital. New York: G.E. Stechert \& Co.

Böhm-Bawerk, E. (1959 [1884]). History and Critique of Interest Theories. South Holland: Libertarian Press - Translated by George D. Huncke and Hans F. Sennholz.

Böhm-Bawerk, E. (1962 [1881]). Whether Legal Rights and Relationships Are Economic Goods. In E. Böhm-Bawerk, Shorter Classics of Böhm-Bawerk: Volume I . (pp. 30 -138). South Holland: Libertarian Press.

Bosma, N. (2013). The Global Entrepreneurship Monitor (GEM) and Its Impact on Entrepreneurship Research. Foundations and Trends in Entrepreneurship 9 (2), 143-248.

Brem, A., Voigt, K. . (2007). Innovation Management in Emerging Technology Ventures The Concept of an Integrated Idea Management. International Journal of Technology Policy and Management, 7(3), 304-321.

Brooke, G. (2010). Uncertainty, Profit and Entrepreneurial Action: Frank Knight's Contribution Reconsidered. Journal of History of Economic Thought, vol. 32(2), 221-235.

Cantillon, R. (1755). Essai sur la nature du commerce en général. Paris: Institut Coopet.

Chell, E. (2008). The Nascent Entrepreneur, Business Development and the Role of Human Resources. In R. \&. Barret, International Handbook of Entrepreneurship and HRM (pp. 21-46). Cheltenham: Edward Elgar. 
Cliff, J.E., Jennings, D. J, Greenwood, R. (2006). New to the Game and Questioning the Rules: The Experiences and Beliefs of Founders Who Start Imitative versus Innovative Firms. Journal of Business Venturing 21 (5), 633-663.

Covin, J.G., Slevin, D.P. (1986). The Development and Testing of an Organizational-Level Entrepreneurship Scale. In R. H. Ronstadt, Frontiers of entrepreneurship research (pp. 628-639). Wellesley, MA: Babs.

Damanpour, F. (1991). Organizational innovation: a meta-analysis of effects of determinants and moderators. Academy of Management Journal, 5 (34) , 555-590.

Drucker, P. (1985). Innovation and Entrepreneurship. Oxford : Butterworth Heinemann.

Eker, A. (91-102). Intellectual Property and R\&D Investment as Measures of Innovation in Switzerland, the USA, and Singapore. International Journal of Arts \& Sciences Vol. 9 (03), 2016.

Estrin, S., Mickiewicz, T. (2010). Entrepreneurship in Transition Economies. The Role of Institutions and Generational Change. IZA Discussion Paper No. 4805.

Eurocontrol. (2018). European Aviation in 2040. Challenges of Growth. Bruxelles: Eurocontrol.

Fetter, F. (1928 [1915]). Economic Principles. New York: The Century Co.

Foss, N.; Klein, P. J. (2012). Organizing Entrepreneurial Judgment a New Approach of the Firm. New York: Cambridge University Press.

Galindo, M.A., Mendez-Picazo, M.T. (2013). Innovation, entrepreneurship and economic growth. Management Decision, 51(3), 501-514.

Golubetskaya, N., Koshelev, T. Kunin, V. (2017). Problems of innovative development of an entrepreneurship in the industry in the conditions of upgrade of Economy. IOP Conference Series: Earth and Environmental Science (90), 1-10.

Gordon, R. (2018). Why has economic growth sloewd when innovation appears to bo accelereating? Cambridge: National Bureau of Economic Research.

Hawley, F. (1907). Enterprise and the productive process: a theory of economic productivity. New York, London: G.P. Putnam's sons.

Hayek, F. ( 1975 [1939]). Profits, Interest and Investment and others Essays on the Theory of Industrial Fluctuations. Clifton: Augustus M. Kelly Publishers.

Hayek, F. (1988). The Fatal Conceit: The Errors of Socialism. Londra: Routledge.

Hayek, F. (2014). Utilizarea cunoașterii în societate. In Individualism și ordine economică (pp. 81-93). Iași: Editura Universităţii Alexandru Ioan Cuza, Iași.

Hayek, F. A. (1960). The Constitution of Liberty. Chicago: The University of Chicago Press.

Henrekson, M., Sanandaji, T. . (2019). Measuring Entrepreneurship: Do Established Metrics Capture Schumpeterian Entrepreneurship? Entrepreneurship Theory and Practice, 1-28.

Horwitz, S. (2019). Ludwig Lachmann as a Theorist of Entrepreneurship. Studies in Logic, Grammar and Rethoric, vol 57(70), 19-40.

Jorgenson, D. W. (2011). Innovation and productivity growth. American Journal of Agricultural Economics, 93(2), 276-296. 
Jorgenson, D. W. (2011). Innovation and productivity growth. American Journal of Agricultural Economics, 93(2), 276-296.

Kanter, R. (1988). When a thousand flowers bloom: structural, collective and social conditions for innovation in organizations. Research in Organizational Behaviour (10), 169-211.

Kirzner, I. (1973). Competition and Entrepreneurship. Chicago, Londra: The University of Chicago Press.

Kirzner, I. (1985). Discovery and the Capitalist Process. Chicago: University of Chicago Press .

Klein, P. (2010). The Capitalist \& The Entrepreneur. Essay on Organizations \& Markets. Alabama: Ludwig von Mises Institute.

Knight, F. (1921). Risk, Uncertainty and Profit. New York: Augustus M. Kelly Bookseller.

Knight, F. (1942). Profit and Entrepreneurial Functions . The Journal of Economic History, Vol. 2, Supplement: The Tasks of Economic History, 126-132.

Kortum, S., \& Lerner, J. (2000). Assessing the Contribution of Venture Capital to Innovation. The RAND Journal of Economics, 31(4), 674-692.

Kortum, S., Lerner, J. ( 2000). Assessing the Contribution of Venture Capital to Innovation. The RAND Journal of Economics, 31(4), 674-692.

Langlois, R. N. (2005). The Entrepreneurial Theory of the Firm and the Theory of the Entrepreneurial Firm. University of Connecticut.

Lassen, A.H., Gertsen, F., Riis, J.E. (2006). The Nexus of Corporate Entrepreneurship and Radical Innovation. Journal Compilation, 15(4), 359-372.

Marshall, A. (1875). The Pure Theory of Foreign Trade - The Pure Theory of Domestic Value. London: London School of Economics and Polical Sciences.

McCaffrey, M., Salerno, J.T. (2014). Böhm-Bawerk's Approach to Entrepreneurship. Journal of the History of Economic Thought (36), 435-454.

Mill, J. (1848). Principles of Political Economy with some of their Applications to Social Philosophy. London: Longmans, Green and Co., http://www.econlib.org/library/Mill/ mIP1.html.

Mises, L. (2018 [1949]). Acțiunea Umană. București: Editura Institutului Ludwig von Mises România, Traducere: Dan Cristian Comănescu.

Mises, L. (2018 [1951]). Profit and Loss. Alabama: Ludwig von Mises Institute.

Papula, J., Kohnova, L., Papulova, Z. (2018). Impact of national culture on innovation activities of companies: a case of Germany, Austria, Switzerland and the Czech Republic. Economic Annals-XXI, Volume 169 (1), 26-30.

Qian, H., Acs, Z.J. . (2013). An absorptive capacity theory of knowledge spillover entrepreneurship. . Small Business Economics (40) , 185-197.

Rothbard, M. (2001). Man, Economy and State. Alabama: Ludwig von Mises Institute.

Say, J. (1821). A Treatise on Political Economy or The Production, Distribution and Consumption of Wealth. New York: Augustus M. Kelley Publishers, https://mises.org/sites/ default/files/A\%20Treatise\%20on\%20Political\%20Economy_5.pdf. 
Schoemaker, P.J.H., Heaton, S., Teece, D. (2018). Innovation, Dynamic Capabilities, and Leadership. California Management Review, 1-28.

Schumpeter, J. (1939). Business Cycles: A Theoretical, Historical, and Statistic Analysis of the Capitalist Process. New York: McGraw-Hill Book Company.

Schumpeter, J. (1942). Capitalism, Socialism, and Democracy. New York: Taylor \& Francis e-Library, 2003.

Stayton, J., Mangematin, V. (2016). Startup time, innovation and organizational emergence: A study of USA-based international technology ventures. Journal of International Entrepreneurship, Vol. 14, 373-409.

Taneja, N. (2002). Driving Airline Business Strategies through Emerging Technology. Burlington: Ashgate Publishing Company .

Wan, D., Huat Ong, C., Lee, F. (2005). Determinants of firm innovation in Singapore. Technovation, Volume 25 (3), 261-268.

Wang, J. (2018). Innovation and government intervention: A comparison of Singapore and Hong Kong. Research Policy, vol. 42(7), 399-412.

Yam, R.C.M., Lo, W., Tang, E.P.Y., Lau, A.K.W. (2011). Analysis of sources of innovation, technological innovation capabilities, and performance: an empirical study of Hong Kong manufacturing industries. Research Policy, 40 (3), 391-402.

Young, A. (1992). A tale of two cities: factor accumulation and technical change in Hong Kong and Singapore. NBER Macroecon. Annu., 7, 13-51.

Zott, C., Amit, R. (2007). Business Model Design and the Performance of Entrepreneurial Firms. Organization Science, 18 (2), 181-199.

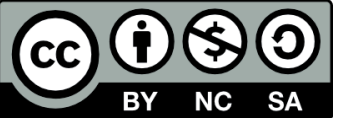

(C) 2022 por la autora. Licencia a ANDULI, Editorial Universidad de Sevilla. Este artículo es un artículo publicado en acceso abierto bajo los términos y condiciones de la licencia Creative Commons Attribution (CC BY) (https://creativecommons.org/ licenses/by-nc-sa/4.0/). 
